\title{
Sightings and Strandings of the Cetacean Fauna in the Mediterranean Coast of the Gaza Strip, Palestine
}

Abdel Fattah N. Abd Rabou'; Mohammed A. Abd Rabou²; Abdel Fattah A. Qaraman ${ }^{3}$; Mazen T. Abualtayef $^{4}$; Asmaa A. Abd Rabou ${ }^{5}$; Norman A. Khalaf ${ }^{6}$; Sara H. Al-Sweirki ${ }^{1}$; Israa M. Jaber ${ }^{1}$; Kamal J. Elnabris ${ }^{1}$; Kamal E. Elkahlout ${ }^{1}$, Ashraf A. Shafei ${ }^{1}$; Amin M. Wafi ${ }^{7}$; Othman A. Abd Rabou ${ }^{7}$; Yousif K. Ibrahim ${ }^{8}$; Atea A. Al-Bursh ${ }^{8}$; Bashar S. Jarayseh ${ }^{9}$; Daoud I. Al-Hali ${ }^{10}$; Khaled A. Hamode ${ }^{11}$; Rimel M. Benmessaoud ${ }^{12}$; Mourad. M. Cherif ${ }^{13}$; Hashem A. Madkour ${ }^{14}$; Fatma A. Madkour ${ }^{15}$ Received: 29 July, 2021, Accepted: 14 Sep, 2021, Published: 1 Oct, 2021 1 Department of Biology and Biotechnology, Islamic University of Gaza, Gaza Strip, Palestine

2 Department of Information Technology, University College of Applied Sciences, Gaza Strip, Palestine

3 Energy and Environment Research Center, Israa University, Gaza Strip, Palestine 4 Department of Environmental Engineering, Islamic University of Gaza, Gaza Strip, Palestine 5 Department of Civil Engineering, Islamic University of Gaza, Gaza Strip, Palestine 6 Department of Environmental Research and Media, National Research Center, Palestine 7 Department of Journalism and Media, Islamic University of Gaza, Box 108, Gaza Strip, Palestine 8 Water and Environment Quality Authority, Gaza Strip, Palestine 9 Environmental Education Center, Beit Jala, West Bank, Palestine 10 Qimmah Secondary School, Al-Quds, Palestine

11 Mshwar Travel, Qlansawa, Palestine

12 National Institute of Agronomy of Tunisia, 43, Avenue Charles Nicolle, 1082, Tunisia

13 National Institute of Marine Sciences and Technologies, INSTM, port de pêche La Goulette, 2060, Tunisia

14 National Institute of Oceanography and Fisheries, Hurghada, Egypt

15 Department of Anatomy and Embryology, Veterinary Medicine, South Valley University, Qena, Egypt

Corresponding Author: Abdel Fattah N. Abd Rabou, arabou@iugaza.edu.ps 


\section{Abstract}

Palestine (27,000 $\left.\mathrm{km}^{2}\right)$ overlooks three seas; namely the Mediterranean Sea, the Red Sea and the Dead Sea. The first two seas are home to a considerable number of cetacean faunistic species. The current descriptive and cumulative study came to document the sightings and strandings of the cetacean fauna in the Mediterranean coast of the Gaza Strip only, which is located in the far southwestern of Palestine with a length of $42 \mathrm{~km}$ on the Mediterranean Sea. The study extended for 40 years starting from 1982 to 2021. It relied much on field visits in addition to meetings and discussions with stakeholders regarding the sightings, strandings and even the bycatch of cetaceans. The current study showed six strandings of dead baleen whales during the past four decades. At least two stranding events were recorded for the Fin Whale (Balaenoptera physalus), which is actually the second largest animal on Earth after the Blue Whale (Balaenoptera musculus). The seawaters of the Gaza Strip were sometimes witnessing special visits, of a number of dolphins with their pods floating at different distances from the sea shore. The number of strandings of the Shortbeaked Common Dolphin (Delphinus delphis) was recorded not more than 3 - 4 times over the past four decades. In contrast, an average number of $1-3$ strandings was recorded annually for the Common Bottlenose Dolphin (Tursiops truncatus) over the past two decades. The causes of local cetacean strandings included incidental falling into fishing nets, shooting by Israeli forces stationed at the Mediterranean Sea, injury and diseases, hunting too close to shore, and climate change. Although the event remained vague, the study highlighted the use of Israel to dolphins equipped with spy devices and cameras to photograph and spy on the marine training activities of the Palestinian resistance in late 2015. Finally, the role of different parties should be harmonized to ensure that human activities are sustainable and compatible with the mandate to preserve local marine natural resources including cetaceans.

Keywords: Cetaceans, sighting, stranding, Fin Whale, dolphins, spy dolphins, Mediterranean coast, Gaza Strip. 


\section{Introduction}

The majority of cetacean fauna (whales, dolphins and porpoises) are marine creatures in the sense that they have a cosmopolitan distribution in all earth's oceans. They are characterized by having streamlined body shape and exclusively carnivorous diet (Boitani and Bartoli, 1983). They propel themselves through the water with powerful up-and-down movement of their tail which ends in a flattened fluke, using their flipper-shaped forelimbs to maneuver. They lack hindlimbs and most of them have a dorsal fin (Castro and Huber, 2009). Cetacean fauna are well known for their high intelligence and complex social behaviors. They utter a wide range of sounds through which they communicate with each other, and navigate through the water by sonar, or echolocation (Boitani and Bartoli, 1983). The Blue Whale (Balaenoptera musculus) may reach a maximum length of 30 meters and weight of 173 tons, making it the largest animal known to have ever existed (Boitani and Bartoli, 1983). The cetacean fauna are split into two main groups: Odontoceti or toothed whales such as the predatory porpoises and dolphins, and Mysticeti or baleen whales such as the filterfeeding whales; of which the Blue Whale (Balaenoptera musculus), the Humpback Whale (Megaptera novaeangliae) and the Bowhead Whale (Balaena mysticetus) are clear examples (Castro and Huber, 2009). Cetacean fauna have been subject to extensive whaling worldwide and are extensively hunted for their meat, blubber and oil (Castro and Huber, 2009). They suffer from fishing pressure, prey depletion and by-catch. Cetaceans also face environmental hazards such as underwater noise pollution, plastic buildup and ongoing climate change. The Chinese River Dolphin (Lipotes vexillifer) is nowadays considered to be functionally extinct because of anthropogenic activity (Castro and Huber, 2009).

Work on cetaceans is very extensive worldwide. This was evident from the large number of scientific references dealing with the biology, ecology and stranding or beaching of baleen and toothed whales. As far as the Middle East and Arab World countries are concerned, many of them were known to produce considerable publications on cetacean biology and ecology. Particular emphasis was paid on the strandings of cetaceans on the coasts of the Mediterranean and Red Seas in addition to the Arabian Gulf. Israel has been producing the most studies in the region relating to 
marine mammals and cetaceans. Kerem et al. (2012) focused on the cetacean fauna occurring in the Mediterranean Levantine basin, and they revealed that diversity of cetacean species in the Levantine basin equals that in the western basins. Brand et al. (2019) pointed out that the Short-Beaked Common Dolphin (Delphinus delphis) has become the second most sighted species in Israeli coastal waters, after the Common Bottlenose Dolphin (Tursiops truncatus). In addition to the previous studies, a lot of Israeli studies have examined the diversity of baleen and toothed whales in the eastern Mediterranean (Goffman et al., 2000; Spanier et al., 2000; Shoham-Frider et al., 2002, 2009, 2014 and 2016; Sharir, 2008; Gaspari et al., 2015; Bearzi, 2017 and Brand et al., 2019).

In Egypt, which is a very close country to Palestine, many recent studies relating to cetaceans were reviewed (Notarbartolo et al 2017; Dawoud et al., 2016; Farrag et al., 2019; Abo-Taleb, 2020; and Mahdy et al., 2021). In Turkey, Iran, Lebanon and Syria, many cetaceans were studied for their biology, ecology and stranding (Öztürk and Öztürk, 1998; Khalaf et al., 2003; Saad, 2004; Öztürk et al., 2011 and Dede et al., 2012). Baldwin (2003) and Baldwin et al. (2004) surveyed some of the baleen whales and dolphins prevailing in the marine environment of Arabia. In the countries of the western Middle East, many pioneer studies dealt with both baleen and toothed whales were carried out in Libya, Algeria, Morocco, Tunisia and Mauritania (UNEP/IUCN, 1994; Notarbartolo et al., 1998; Taleb and Boutiba, 1999; El Hili et al., 2010; RojoNieto et al., 2011; Benmessaoud et al., 2012 and 2020; Larbi Doukara et al., 2014; Bouslah et al., 2016; Masski and De Stephanis, 2018; Larbi Doukara, 2019 and Rizgalla, 2020).

Palestine overlooks three seas: The Mediterranean Sea, the Red Sea and the Dead Sea. Cetaceans and other marine organisms thrive in the waters of the Mediterranean and Red Seas, but they are completely absent in the Dead Sea. The Dead Sea, also known as the Salt Sea, is called "dead" because its high salinity that prevents macroscopic aquatic organisms, such as fish and aquatic plants, from living in it despite the trace amounts of microbial bacteria and fungi that are present. Table 1 shows whales (baleen and toothed) that were seen at sea or stranded on the coasts of the Mediterranean and Red Seas in Palestine during the past decades as explained by 
several authors (Ministry of Environmental Affairs - MEnA, 2001; Khalaf, 2008, 2012, 2019 and 2021a, b and c; Kerem et al., 2012; Abd Rabou, 2020; TOI Staff, 2020 and Jerusalem Post Staff, 2021).

Table 1: Cetaceans (baleen and toothed whales) which have been sighted offshore or have stranded on the Mediterranean and Red Sea coasts of Palestine

\begin{tabular}{|c|c|c|c|}
\hline Family & Scientific Name & Common Name & Arabic Name \\
\hline \multirow[t]{5}{*}{ Balaenopteridae } & Balaenoptera musculus & Blue Whale & الحوت الأزرق \\
\hline & $\begin{array}{l}\text { Megaptera } \\
\text { novaeangliae }\end{array}$ & Humpback Whale & الحوت الأحدب \\
\hline & Balaenoptera brydei & Bryde's Whale & حوت بريدي \\
\hline & Balaenoptera physalus & Fin Whale & الحوت الزعنفة \\
\hline & $\begin{array}{l}\text { Balaenoptera } \\
\text { acutorostrata }\end{array}$ & Minke Whale & حوت المنك \\
\hline Physeteridae & $\begin{array}{l}\text { Physeter } \\
\text { macrocephalus }\end{array}$ & Sperm Whale & حوت العنبر (الحوت المنوي) \\
\hline Ziphiidae & Ziphius cavirostris & Cuvier's Beaked Whale & حوت كوفييه ذو المنقار \\
\hline Eschrichtiidae & Eschrichtius robustus & Gray Whale & الحوت الرمادي \\
\hline \multirow[t]{12}{*}{ Delphinidae } & Orcinus orca & Killer Whale (Orca) & الحوت القاتل أو السفاح (الأوُركا) \\
\hline & Pseudorca crassidens & False Killer Whale & الحوت القاتل أو السفاح الكاذب \\
\hline & Grampus griseus & Risso's Dolphin & دولفين ريسو \\
\hline & Tursiops truncatus & Common Bottlenose Dolphin & الدولفين الثائع قاروري الأنف \\
\hline & Tursiops aduncus & $\begin{array}{l}\text { Indo-Pacific } \quad \text { Bottlenose } \\
\text { Dolphin }\end{array}$ & $\begin{array}{l}\text { الدولفين الهندي الباسفيكي قاروري } \\
\text { الأنف }\end{array}$ \\
\hline & Delphinus delphis & $\begin{array}{l}\text { Short-beaked Common } \\
\text { Dolphin }\end{array}$ & الدولفين قصير المنقار الثائع \\
\hline & Delphinus tropicalis & Arabian Common Dolphin & الدولفين العربي الثشائع \\
\hline & Sousa chinensis & $\begin{array}{l}\text { Indo-Pacific Humpback } \\
\text { Dolphin }\end{array}$ & الحوت الهندي الباسفيكي الأحدب \\
\hline & Steno bredanensis & Rough-toothed Dolphin & الدولفين خشن الأسنان \\
\hline & Stenella attenuata & Pantropical Spotted Dolphin & الدولفين المداري المرقط \\
\hline & Stenella longirostris & $\begin{array}{l}\text { Long-snouted } \\
\text { Dolphin }\end{array}$ & الدولفين الدوار طويل الخطح \\
\hline & Stenella coeruleoalba & Striped Dolphin & الدولفين المخطط \\
\hline
\end{tabular}

As far as the Palestinian Territories are concerned, special, deep works on cetaceans have never been found. All that is available are some marine reports or studies that 
indicated the occurrence of some marine life, including some cetaceans, in the Mediterranean waters of the Gaza Strip (MEnA, 2001; Abd Rabou et al., 2007a and b; Abd Rabou, 2013 and 2020). For example, Euroconsult and IWACO (1994) mentioned that little is documented on the marine mammals of the Gaza Strip, with the status of the Monk Seal (Monachus monachus) remains unclear, despite the fact that the species was resighted along the Mediterranean coast of region (Scheinin et al., 2011). MEnA (2001) pointed out that dolphins are regularly reported but are far less common than in the western Mediterranean. Two dolphin species have been observed by Gazan fishermen; these are the Short-beaked Common Dolphin (Delphinus delphis) and the Common Bottlenose Dolphin (Tursiops truncatus). None of these cetaceans have been preserved or stuffed at the zoological exhibitions of the universities of the Gaza Strip (Abd Rabou, 2020 and Abd Rabou et al., 2020) . There are some non-in-depth studies that indicated the occurrence or beaching of cetacean species in the coastal waters of historic Palestine (Khalaf, 2008, 2012, 2019 and 2021a, b and c). Cetacean stranding, commonly known as beaching, is a phenomenon in which whales and dolphins strand themselves on land, usually on a beach. Beached whales often die due to dehydration, collapsing under their own weight, or drowning when high tide covers the blowhole. During the last 40 years, along with the cetacean sighted cases, some stranded cases of cetaceans were recoded on the Mediterranean coast of the Gaza Strip.

In fact, the Palestinian Mediterranean seawaters of the Gaza Strip have no clear data on the occurrence and distribution of cetacean fauna. This is simply because the Palestinians have no complete political accessibility or control on their seawaters or even their fishing zone that are usually militarily controlled by Israel. Moreover, the navigation or fishing fleet is very modest to the extent that the data concerning the ichthyofauna and cetacean fauna of the Mediterranean ecosystem of the Gaza Strip are scarce and imprecise. The Palestinian Territories generally suffer from a lack of specialists and academics in the fields of marine ecology and marine resources. Therefore, there are no focused and specialized studies related to marine ecology, especially marine mammals. In spite of all these obstacles, the current descriptive study comes to document the sightings and strandings of the cetacean fauna in the Mediterranean coast of the Gaza Strip, Palestine. The importance of the study comes 
from the fact that it is the first local study dealing with the cetacean fauna in the Gaza Strip.

\section{Materials \& Methods}

\subsection{The Gaza Strip}

The Gaza Strip $\left(31^{\circ} 25^{\prime} \mathrm{N}, 34^{\circ} 20^{\prime} \mathrm{E}\right)$ is an arid to semi-arid strip of the Palestinian land along the southeastern Mediterranean (Figure 1), having an area of $365 \mathrm{~km}^{2}$, and a population of about 2.2 million, of whom the majority are United Nations-registered refugees. The Gaza Strip is one of the most densely populated places in the world (United Nations Environmental Program - UNEP, 2003). It has a total number of about 3,500 fishermen working on more than 1,000 fishing vessels of different sizes and capacities (MEnA, 2001). The total production of fisheries resources is about 3,480 tons per year. The accessibility and exploitation of Gazan fishermen to the fluctuating fishing area is often governed by the Israeli occupation. The Directorate General of Fisheries Resources, Ministry of Agriculture, is the competent, responsible and authorized authority to ensure the maximum utilization of fishery resources in the Palestinian Territories.

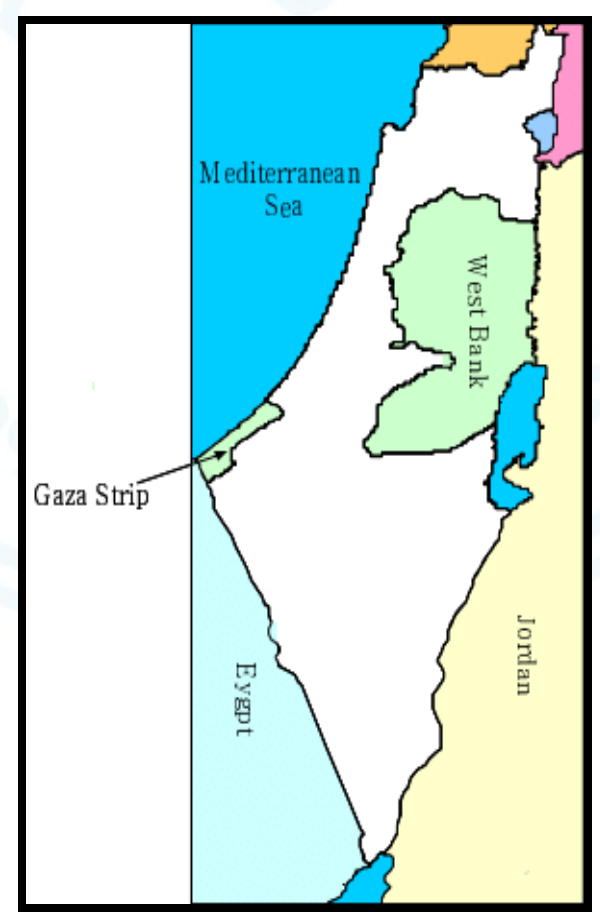

Figure (1): Location of the Gaza Strip at the Southwestern Corner of Palestine 


\subsection{Data Collection}

The current study is cumulative and descriptive in its style, extending for 40 years starting from 1982 to 2021. Frequent regular and irregular visits have been carried out to the coast of the Gaza Strip which extends about $42 \mathrm{~km}$ along the Mediterranean Sea, Gaza Fishing Harbor and fish markets in an attempt to study marine biota. Meetings and discussions with the staff of the Directorate General of Fisheries Resources of the Ministry of Agriculture, Gazan fishermen, marine police, sea-goers and even normal people visiting the Mediterranean beaches of the Gaza Strip have been carried out to fill the gaps needed in data collection concerning cetacean and even fish fauna. During the study period, data have been gathered from the stakeholders regarding the sighting, stranding and even bycatch of cetaceans.

The following sources of information were good contributors for the identification of cetacean species occurring at the Mediterranean coast of the Gaza Strip:

- Stranded cetacean specimens on the beach of the Gaza Strip were identified by the researchers. When badly decomposed or semi-decomposed specimens were difficult for definite identification, photos were sent to specialists abroad. This was applicable for the Fin Whale (Balaenoptera physalus), Common Bottlenose Dolphin or Atlantic Bottlenose Dolphin (Tursiops truncatus) and Short-beaked Common Dolphin (Delphinus delphis). Because stranding of cetaceans on the Palestinian Mediterranean coastline of the Gaza Strip is a discrete and an irregular phenomenon, nearly all cetacean beachings are reported and documented.

- Dolphins incidentally caught by local fishing gear were identified as well either by the authors or the clever Gazan fishermen who have good experience with dolphins.

- Open sea and opportunistic sightings of cetaceans by Gazan fishermen and other marine parties such as navy and marine police. In the last decade, when mobile phones with good cameras became popular, some seafarers, fishermen and others, managed to take some photos and sometimes videos of dolphins accompanying their boats or facing them at sea.

- Reliance on some scientific references and reports that document the occurrence of cetaceans in the marine waters of the Gaza Strip. It should be noted here that there 
are some Israeli studies that were reviewed during the study, which showed repeated sightings of some cetaceans in the Mediterranean coasts of the Gaza Strip, with the study of Kerem et al. (2012) was a good example.

- Reliance on the various Palestinian and sometimes Israeli news and social media websites to gather information regarding the cetacean fauna of the Palestinian coast on the Mediterranean Sea. In fact, the Palestinian public has become aware of the stranding of dolphins, especially the Common Bottlenose Dolphin (Tursiops truncatus), on the seashore of the Gaza Strip. This comes as a reflection of the development of social media in Palestine, where these means easily broadcast photos and videos of rare marine creatures stranding on the beach, including some species of whales, dolphins, strange fishes and sea turtles.

\section{Results}

\subsection{Incidents of Sightings and Strandings of Baleen Whales in the Gaza Strip}

There was a limited number of whale strandings and sightings from the Gaza Strip in the last 40 years as follows:

1. In the 1980s, two unidentified whales stranded on the beach of the Gaza Strip were recorded. Some Gazans recalled the stranding of a whale in 1987 on the beach of Deir El-Balah in the middle of the Gaza Strip as illustrated in Figure 2. The Department of Biology at the Islamic University of Gaza brought a small part of the skeleton of the last whale, which at that time reached more than 18 meters in length, for conservation purposes. Unfortunately, this part of the skeleton did not last long for unknown reasons. It was said that the whale was exposed to Israeli fire at that time after it was assumed that it was a submarine.

2. In the early 1990s, a long, unidentified whale stranded on the beach of Deir ElBalah, in the middle of the Gaza Strip. No clear data were available regarding that event.

3. In the mid-1990's, a long decomposing, unidentified whale stranded in Khan Yunis, south of the Gaza Strip. Because of the stench that emanated from it and repeated people's complaints, the carcass of that whale was burned. 


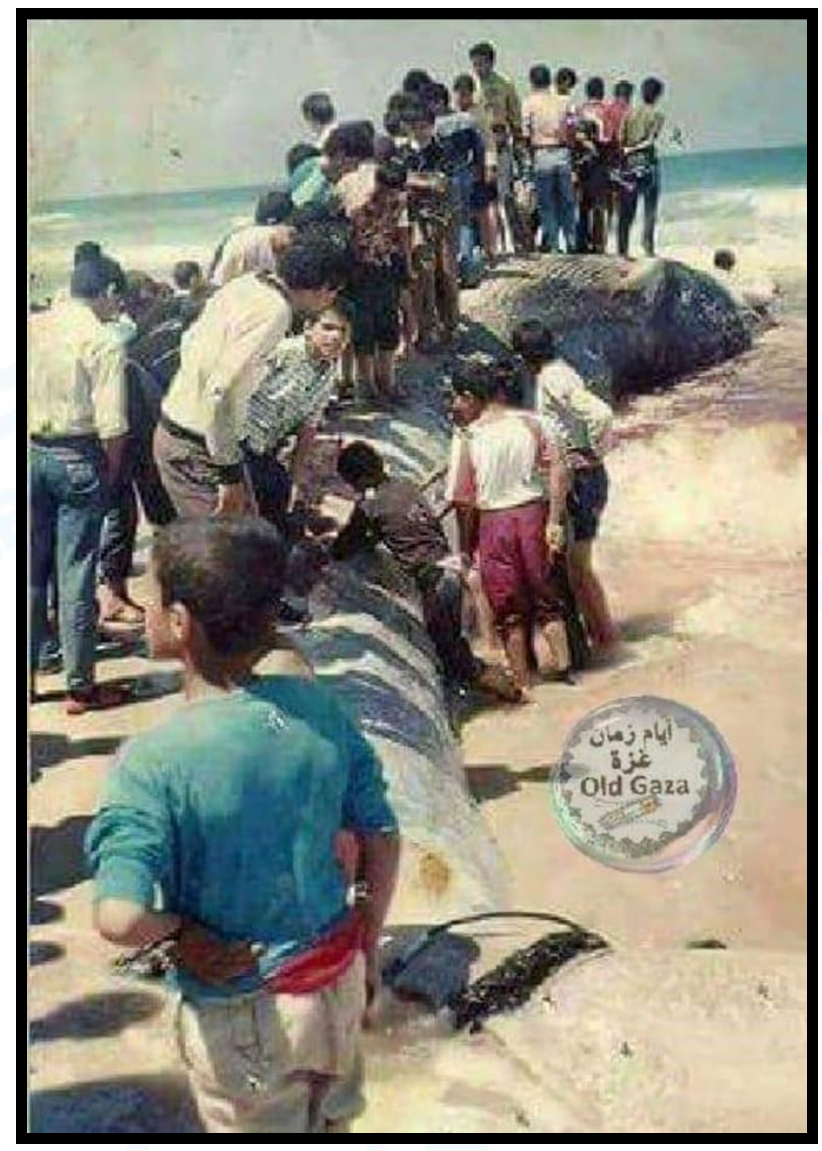

Figure 2: A Baleen Whale Was Washed Ashore on the Beach of Deir El-Balah in the Middle of the Gaza Strip in 1987

4. In June 3, 2009, a dead whale was seen in a deteriorating and almost decomposing condition on the shores of the city of Rafah in the southern Gaza Strip (Figure 3). A field observer said that the Israeli gunboats that were stationed at sea fired its shells towards that whale after it was believed to be a submarine, which led to its stranding on the beach after its death. The citizens were surprised by the exit of this whale, which was estimated to have 810 meters long, on the beach. The whale was covered with wounds and blood, and it came out on the beach as a dead body. The advanced state of decay of the stranded whale may lead to the thought that it died one to two weeks before its shooting by Israeli army and later beaching. It was not possible for scientific forums to see it or preview it. Video clips and photos narrating that event are the remains of the effects of that whale. After consultation with regional experts and scientific parties, the stranding whale was identified as a Fin Whale (Balaenoptera physalus), the second-biggest mammal 
species in the world after the Blue Whale (Balaenoptera musculus). It was the same species of dead whales that stranded at that time on the shores of many countries including Tunisia, Algeria and Kuwait.

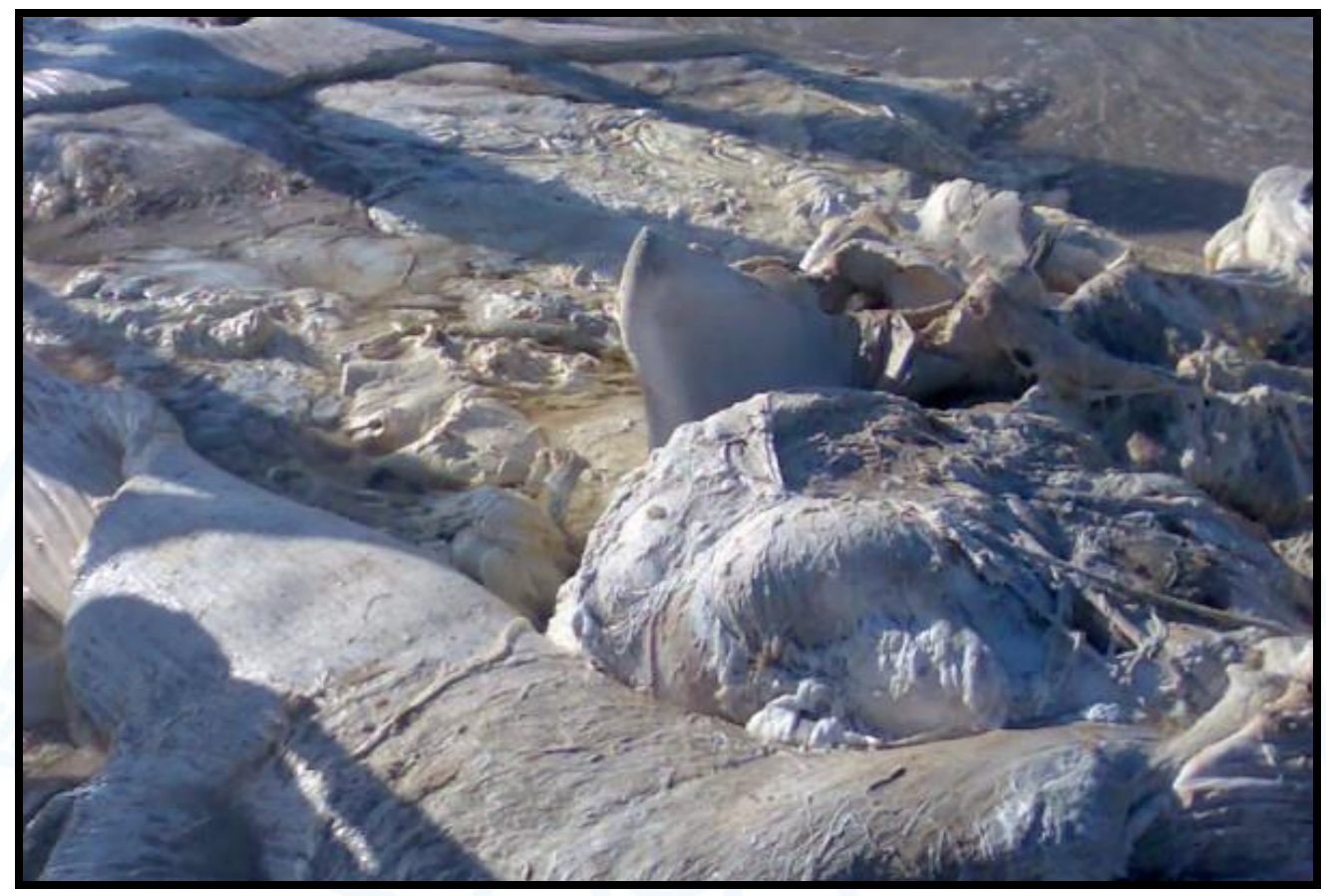

Figure (3): Parts of the Decaying Fin Whale (Balaenoptera physalus) Which Was Washed Ashore on the Rafah Beach, Southern Gaza Strip on June 3, 2009

5. In a recent sighting, social media pioneers circulated a video clip in April 2019, showing a large, thin-bodied whale wandering among the Gazan fishermen's boats in the open sea of the Gaza Strip. The video clip shows the size of the whale as it swims among the fishermen's boats at night while they are practicing fishing in the Sea. The story began when the fishermen felt during their work on their boats off the shores of Gaza City, a strange movement in the water, and the emergence of something like a fountain (blow spout), so that the fishermen became sure that there was a whale wandering among and under their boats. The fishermen were amazed at the whale's length, speed and blow spout. No one has been able to identify the whale species due to its blazing speed and nighttime appearance. There were indications that it was probably the Fin Whale (Balaenoptera physalus), but there is no certainty about its exact identity. 
6. In a very recent stranding of whales, a dead male Fin Whale (Balaenoptera physalus), reaching a length of 16.9 meter and weighing about 25 tones, was washed ashore on a beach in the southern Palestinian city of Al-Majdal (Asqallan or Ashkelon); several kilometers from the north of the Gaza Strip on February 18, 2021 (Figure 4). The dead Fin Whale was initially thought to have been connected to the tar pollution, which killed many marine animals. Later, Israeli experts determined that the whale was in an advanced state of decay, which means that it died about two weeks before its stranding on AlMajdal Beach.

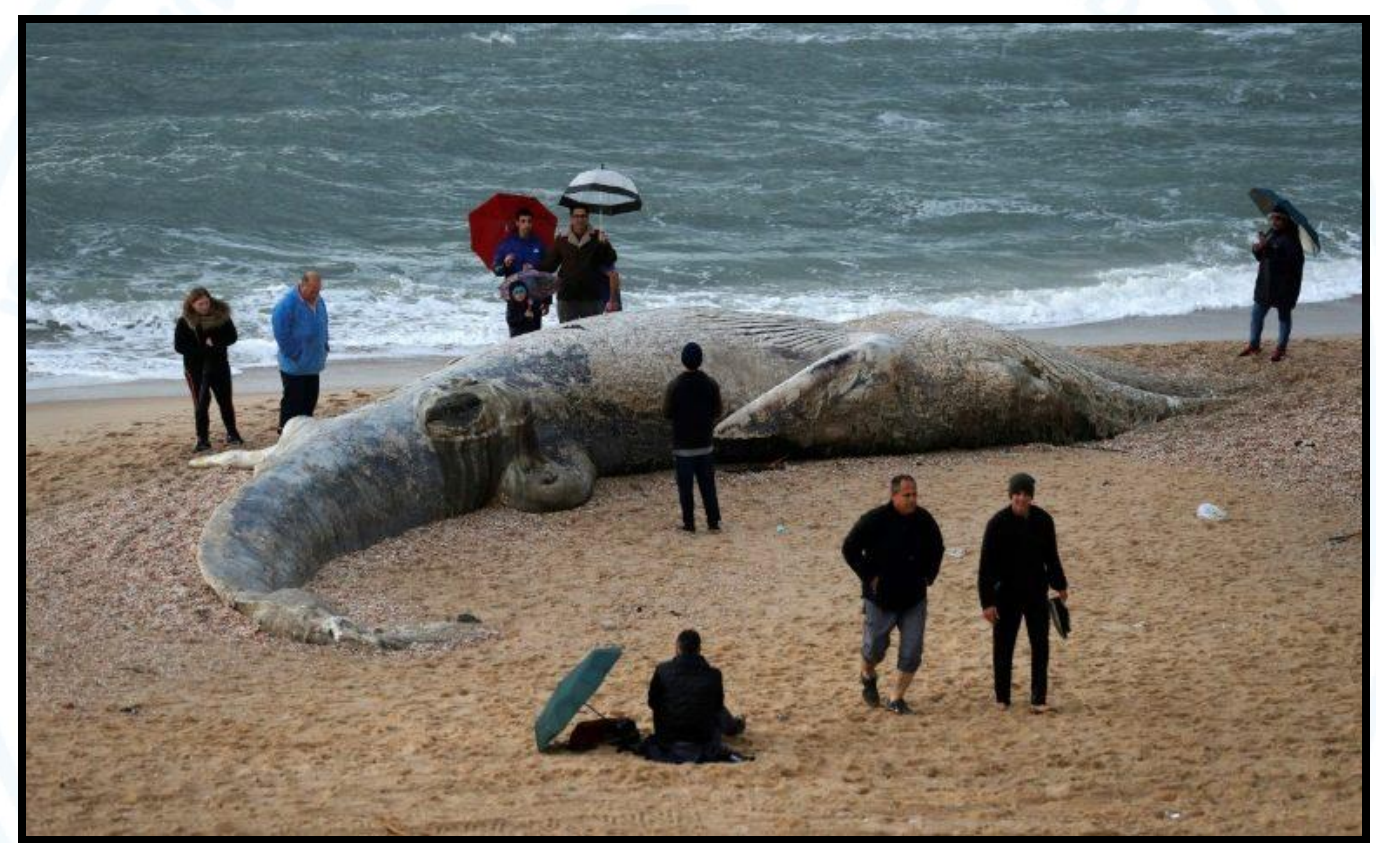

Figure (4): A Dead Male Fin Whale (Balaenoptera physalus) Was Washed Ashore on February 18, 2021, on the Beach of Al-Majdal (Ashkelon), A Southern Palestinian City Lying Several Kilometers North of the Gaza Strip

\subsection{Incidents of Sightings and Strandings of Toothed Whales in the Gaza Strip}

In fact, dolphins (toothed whales) are the marine mammals most watched by fishermen at sea or stranded on the Mediterranean coast extending for $42 \mathrm{~km}$ in the Gaza Strip. The sea waters of the Gaza Strip are sometimes witnessing special visits, of a number of dolphins with their pods floating at different distances from the sea 
shore as pointed out by Gazan fishermen (Figure 5). Many fishermen have reported that some of the dolphins fall into their fishing nets and that they are trying to free them from the nets and return them to the water because they have babies that need feeding and care. Unfortunately, some dolphins may die before they are released and are dumped at sea or ashore. The Common Bottlenose Dolphin (Tursiops truncatus) is the most common dolphin in the marine waters of the Gaza Strip, and it represents between $90-95 \%$ of the volume of sightings at sea compared to the Short-beaked Common Dolphin (Delphinus delphis) that is rarely seen at sea. But if the matter is related to cases of stranding of live or dead dolphins, most of the dolphins stranded on the shore of the Gaza Strip are dead or at the last moments of their death, and some of them have been shot by the Israeli army stationed in the Mediterranean and off the coast of the Gaza Strip continuously.

According to the opinions of some fishermen and interested people, the stranding of the Short-beaked Common Dolphin has been recorded not more than $3-4$ times over the past four decades. On the other hand, an average of $1-3$ strandings of Common Bottlenose Dolphins is recorded annually. In 2021 alone, four strandings of the species were noted and recorded. Strandings of the Common Bottlenose Dolphin in the Gaza Strip occur from time to time in an irregular mean rate of a few individuals per year. The stomach contents have never been retrieved from the stranding dolphins in order to give an insight into their dietary habits. Despite the recorded stranding operations of dead dolphins along the Palestinian coast in the Gaza Strip and throughout the months of the year (Figure 6), there is a clear record of stranding during the winter months of the year extending from November to April. 


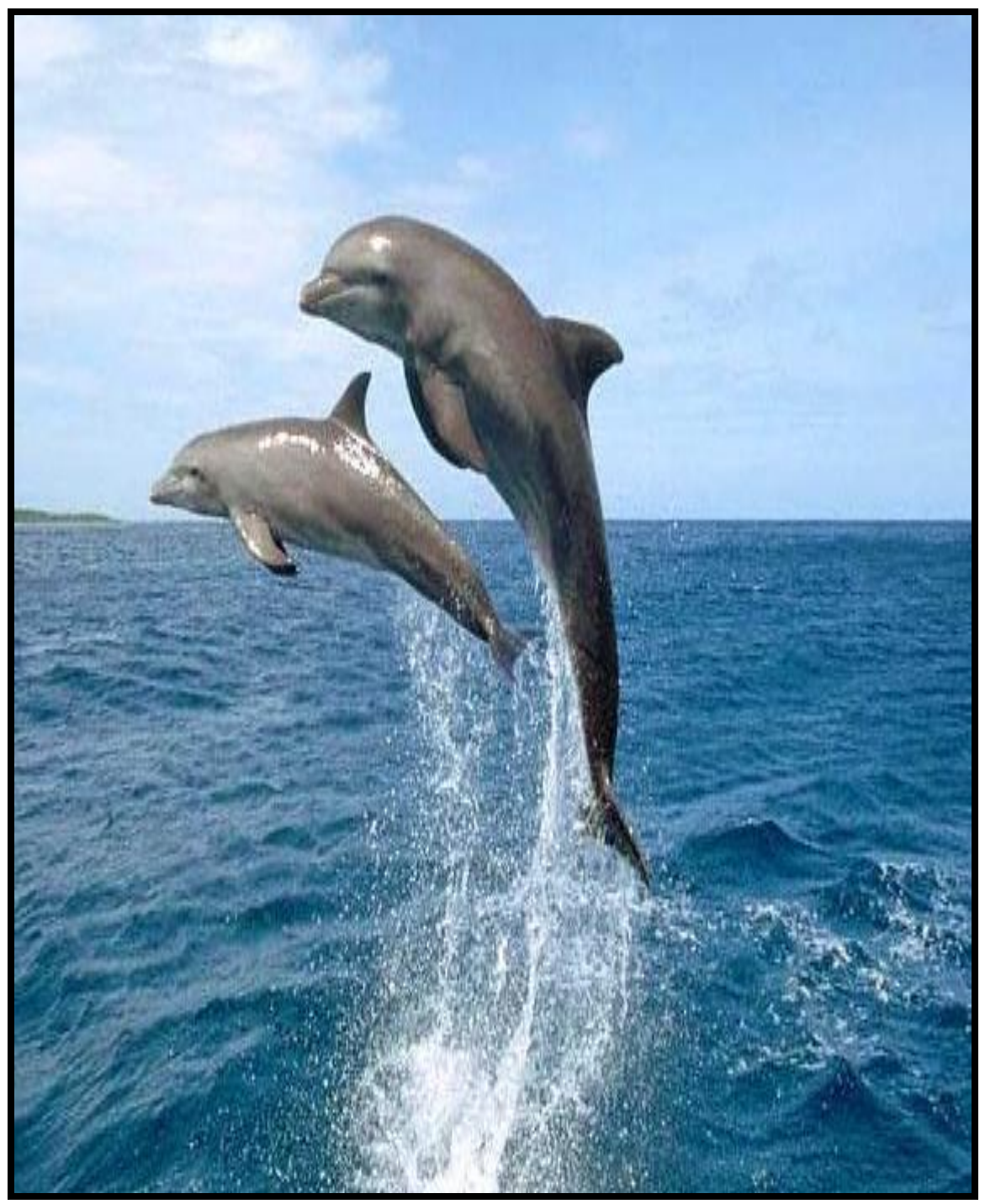

Figure (5): Common Bottlenose Dolphins (Tursiops truncatus) with Their Pods Floating at Different Distances from the Sea Shore of the Gaza Strip in December 2013 (https://www.fatehgaza.com/post/471) 

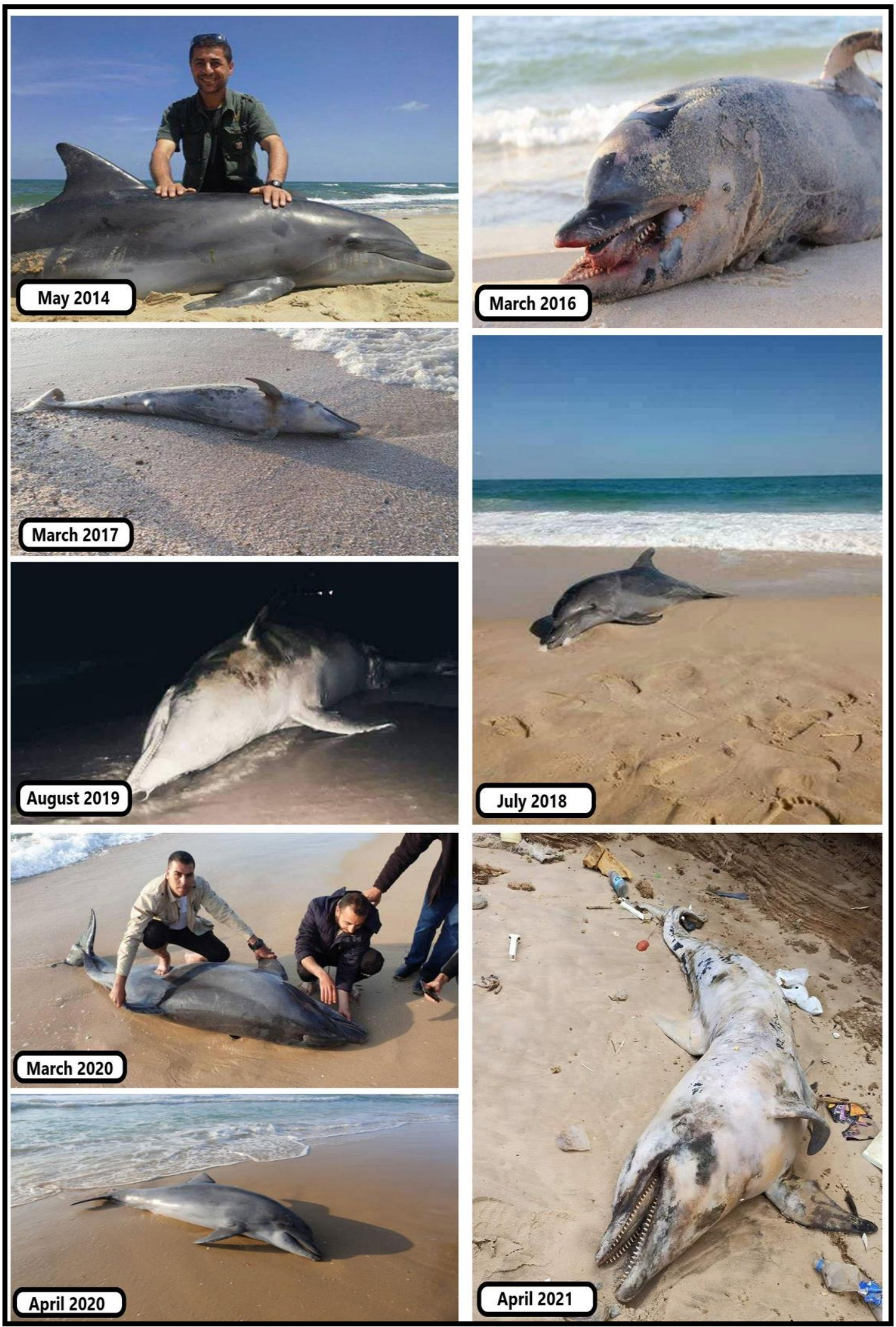

April 2020

Figure (6): Some Strandings of Dead Common Bottlenose Dolphins (Tursiops truncatus) Along the Palestinian Coast of the Gaza Strip in Various Years 


\subsection{Discovery of an Israeli "Spy Dolphin" in the Gaza Strip}

In late 2015, several Palestinian and non-Palestinian media sites reported that the "spy dolphin" was one of the latest Israeli innovations used to spy on the Palestinian resistance in the besieged Gaza Strip since 2006 (Figure 7). These sites stated that the naval commando unit of the Al-Qassam Brigades, the military wing of Hamas, during its training in the depths of the Mediterranean in the Gaza Strip, found a spy device and cameras installed on the back of a dolphin. The identity or type of the dolphin was not determined. The naval commando unit of the Al-Qassam Brigades controlled the spy dolphin and dismantled what it was carrying. The Palestinian resistance believes that the task of such dolphins is to photograph and spy on the training of human frog units. Hebrew newspapers later indicated that the spy dolphin also carried a device capable of shooting arrows in a way that would allow a person to be injured or killed. Despite the multiplicity of media sites that published the news and the abundance of stories, the whole topic remained vague and no photos were published about that spy dolphin.

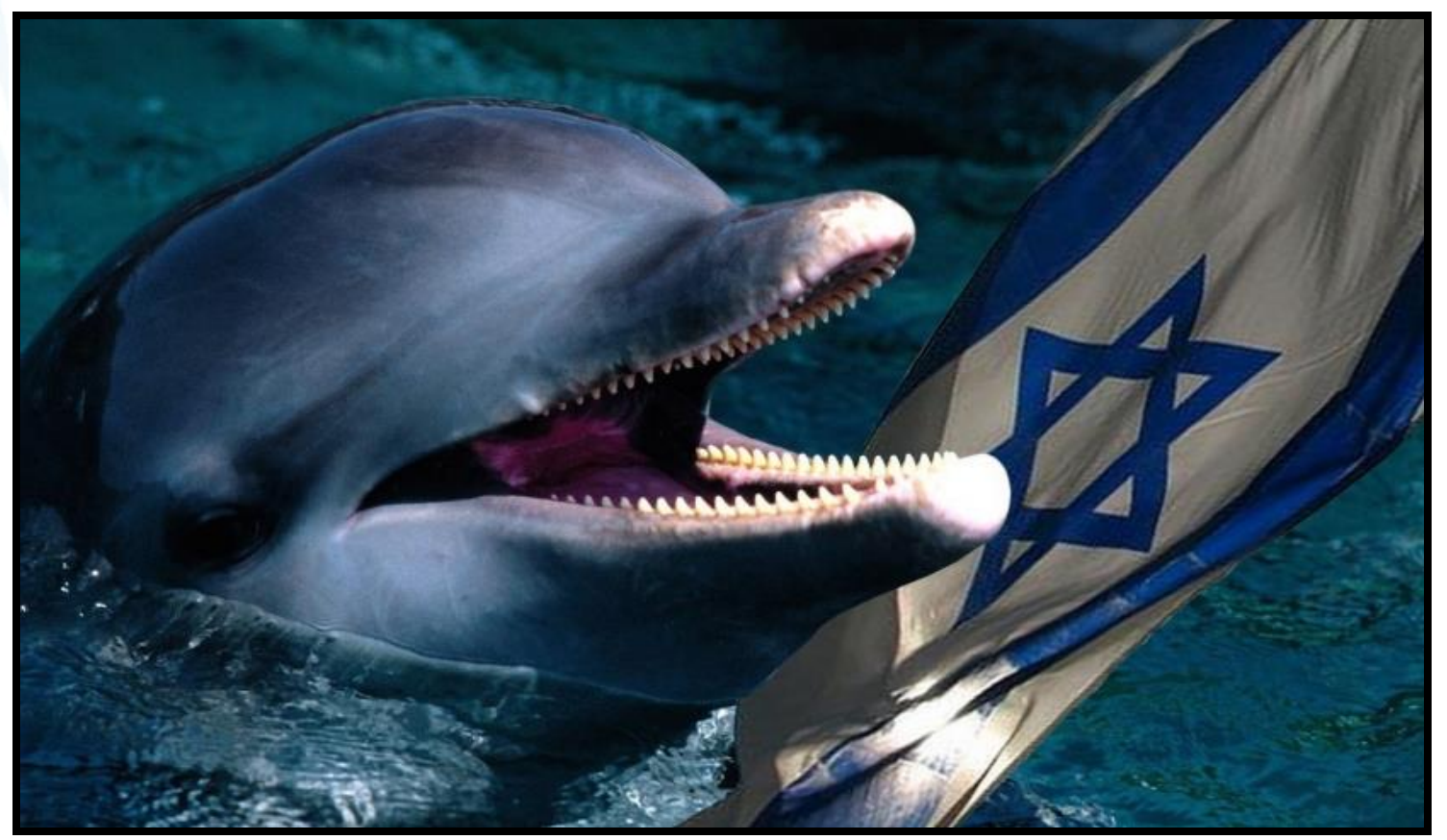

Figure (7): An Illustrative Photograph of Israel's Exploitation of Dolphin for the Purposes of Spying on the Palestinian Resistance in the Gaza Strip [Source: Noonpost (2016): https://www.noonpost.com/content/15207] 


\subsection{Notes on the Cetaceans of the Gaza Strip}

\subsubsection{Fin Whale (Balaenoptera physalus, Linnaeus 1758)}

During the last 4 decades, a very few single individuals of baleen whales were encountered swimming at open sea by Gazan fishermen, and at least, six strandings of dead baleen whales were recorded. Two of these strandings were identified as Fin Whales (Balaenoptera physalus). The Fin Whale is the second largest animal on Earth after the Blue Whale (Balaenoptera musculus), which can reach a length of more than 30 meters. It is one of the fastest whales as well. Despite the relative smallness of the samples that came to the shores of the Gaza Strip and Al-Majdal, a few kilometers north of the Gaza Strip, the average length of adult specimens of the mammal may reach 24 meters and weighs about 70 tons. The Fin Whale, which is considered a cosmopolitan species in the sense that it is found in the entire world's oceans, has a long and thin body and is gray in color, and it feeds on flocks of small fish, squid and crustaceans. Like other baleen whales, the species is threatened because of its extensive hunting for the purpose of obtaining its fat, oil, and baleen plates.

\subsubsection{Common Bottlenose Dolphin (Tursiops truncatus, Montagu 1821)}

This is the most frequently encountered species either as sightings at open sea or strandings on the Palestinian waters and coasts throughout the year and along the entire coastline of the Gaza Strip. Since it is difficult for fishermen or the Palestinian navy to exceed the distance specified for sea fishing by Israel, cetacean watching and fishing operations are limited to a few nautical miles from the shore. During the past 20 years, stranding of this species on the shore is more frequent among cetaceans, at a rate of $1-3$ stranding per year, and most of the specimens were dead and sometimes decomposed. On the other hand, seeing this dolphin alone or in groups has been largely confirmed by some fishermen and even some other marine forums that are accustomed to frequenting the sea for different purposes (Figures 5 and 6). As claimed by Gazan fishermen, the species was found to cooperate with local fishermen by driving fish toward the fishermen and eating the fish that escape the fishermen's 
nets. In November 2016, a Common Bottlenose Dolphin was exposed to two bullets by the Israeli forces, which led to its death. The dolphin arrived at the sea shore dead, weighing about 25 to 30 kilograms. The fishermen left it on the beach, while people gathered around it in a state of astonishment and amazement and took photos and shared them on social media.

In fact, the Common Bottlenose Dolphin is a very common dolphin species that it inhabits warm and temperate oceans all over the world. It is very common in the Mediterranean Sea. It is the most common dolphin because of the wide exposure it receives in captivity, marine parks, and aquarium and television shows. In most parts of the world, the length of adult Common Bottlenose Dolphin is between 2.5 and 3.5 $\mathrm{m}$ with weight ranging between 200 and $500 \mathrm{~kg}$. Many threats were found to affect the populations of dolphins worldwide. These included marine pollution like oil spills, chemical discharges, and hunting for food purposes. Also, dolphins are sometimes killed inadvertently as a bycatch of fishing.

\subsubsection{Short-Beaked Common Dolphin (Delphinus delphis, Linnaeus 1758)}

In contrast to the occurrence of the Common Bottlenose Dolphin, the Short-beaked Common Dolphin is a rarely encountered species either as sightings or strandings on the Palestinian waters and coasts throughout the year and along the entire coastline. During the past twenty years, the stranding of this species on the beach was limited to nearly four dead samples, according to the local maritime forums, including the fishermen. Conversely, seeing this dolphin alone or in groups has been confirmed by some fishermen who are accustomed to frequenting the sea and fishing.

\subsection{Possible Causes of Cetacean Strandings in the Gaza Strip}

In spite of the repeated sightings of dolphin at sea in the Gaza Strip, the incidents of strandings of both baleen and toothed whales were well documented on the coastline of the Gaza Strip. The causes of death of most of these dolphins were vague, but the meetings and discussions of the researchers with Gaza fishermen and other stakeholders revealed many causes of death that end with shore strandings as follows: 
1. Incidental falling into fishing nets: There have been many incidents, as told by Gazan fishermen, of dolphins falling into fishing nets because of their attempt to catch the caught fish. Some of these accidents cause dolphins to suffocate and die.

2. Shooting by Israeli forces: Many Gazan fishermen and marine police pointed out that many cetaceans including baleen whales and dolphins were found to be shot by Israeli forces because they mistaken them with submarines.

3. Sonar effects: The maneuvers carried out by the Israeli navy or other foreign navies in the high seas using sonar and other military devices which emit waves and pulses that act as worrisome for dolphins and make them subject to stranding.

4. Injury: There are many injuring causes that may face whales and dolphins in open sea. Such injuries cause fatigue and weakness that render them unable to swim and as a result these creatures swept by sea current to the shores.

5. Diseases: Like injuries, the various diseases that whales and dolphins face in the seas result in their weakness and inability to swim and dive. Finally, the sea waves and currents threw them exhausted or dead on the shores.

6. Strong winds and waves: Dolphins were sometimes believed to be drifted to shore due to strong winds and waves especially in the winter seasons as claimed by many Gazan fishermen.

7. Marine pollution by various chemicals: Like fish, cetaceans are subject to various chemical pollutants coming from various sources. Tar pollution, for example, is fatal for many marine creatures.

8. Hunting too close to shore: The practice of hunting of dolphins to their preys near the shores may contribute to their collisions with bottoms and the ultimate beachings.

9. Suicide: There was a good thought among the Gazan marine parties that dolphins sometimes commit suicide by throwing themselves on the beach, though dolphin mass suicides have never been recorded in the Gaza Strip. The Gazans acquired the culture of suicide of whales, especially dolphins, from the frequent scenes presented by satellite channels, news sites, and social media sites, which show groups of dolphins coming to the beach. Some of them die and the citizens of countries return others to marine waters so that they can be alive again. 
10. Climate Change: It is believable that the raise of marine temperature due to the global climate change phenomenon may result in marine creature strandings.

\section{Discussion}

The current study is a descriptive in its style trying to document the cetacean fauna (baleen and toothed whales) occurring or stranding on the Mediterranean coast of the Gaza Strip, Palestine. In fact, conducting in-depth studies on this subject in the Gaza Strip seems to be impossible due several factors. First, the small fishing area of the Gaza Strip is totally governed by Israel which at its best does not exceed 12 nautical miles, although what was stipulated in the political agreements allows the Palestinians to fish up to 20 nautical miles. Nevertheless, since the signing of the Oslo Agreement in 1994 until now, the fishing area fluctuates between 3 - 12 nautical miles, depending on the political, military and security conditions that the Israelis specify. The Palestinians have been forbidden from navigation in the high sea and as a result, the Palestinian marine resources have been not fully studied or surveyed. Second, there is a complete lack of specialists who are relating to marine ecology and marine biodiversity, especially the marine mammals. For this reason, it was difficult to know the nature of most of the whales that stranded on the coast of the Gaza Strip during the past 40 years, as the current study showed. Third, the Palestinian marine technical potential in terms of the marine fleet is very poor and old to the extent that it cannot meet the current fishing conditions, let alone in-depth studies of fish stocks and other marine creatures such as whales and other marine mammals. For example, Kerem et al. (2012) showed that a single Fin Whale was spotted $55 \mathrm{~km}$ off Gaza over a bottom depth of $600 \mathrm{~m}$, so how could the Palestinians document such gigantic creatures when they could not freely fish in the fishing area permitted to them by Israel? Based on the above, the current study relied more clearly on cetacean strandings that come to the beach in the Gaza Strip. Furthermore, the data of this study contribute to the knowledge of the poorly known cetacean fauna of the Palestinian shores of the Mediterranean Sea. 
The current study showed the strandings of six baleen whales during the past four decades. The most recent of which was in February 2021 in southern Palestine, a few kilometers from the north of the Gaza Strip, where a dead specimen of a Fin Whale measuring 17 meters in length stranded. The multiplicity of strandings of both baleen and toothed whales on the small coast of the Gaza Strip, which is $42 \mathrm{~km} \mathrm{long}$, demonstrates the importance of the eastern Mediterranean basin in housing a considerable number of cetaceans as a lot of studies demonstrated (Weitkowitz, 1992; Öztürk and Öztürk, 1998; Kerem et al., 2012; Khalaf et al., 2003; Bazairi et al., 2010; Öztürk et al., 2011; Dede et al., 2012; IUCN, 2012; Shoham-Frider et al., 2014 and 2016; Gaspari et al., 2015; Bearzi, 2017; Farrag et al., 2019; Abo-Taleb, 2020 and Stephens et al., 2021). As an indication of the importance of the Palestinian Mediterranean waters in harboring a diversity of cetaceans; particularly dolphins, a 2,000-year-old and 16-inch dolphin statue clutching a fish between its jaws, carved from marble, appeared during an Israeli archaeological excavation near Kibbutz Magen (12 miles inland from the Mediterranean Sea), on the border with the Gaza Strip, in March 2015 as illustrated in Figure 8 (Ben Zion, 2015).

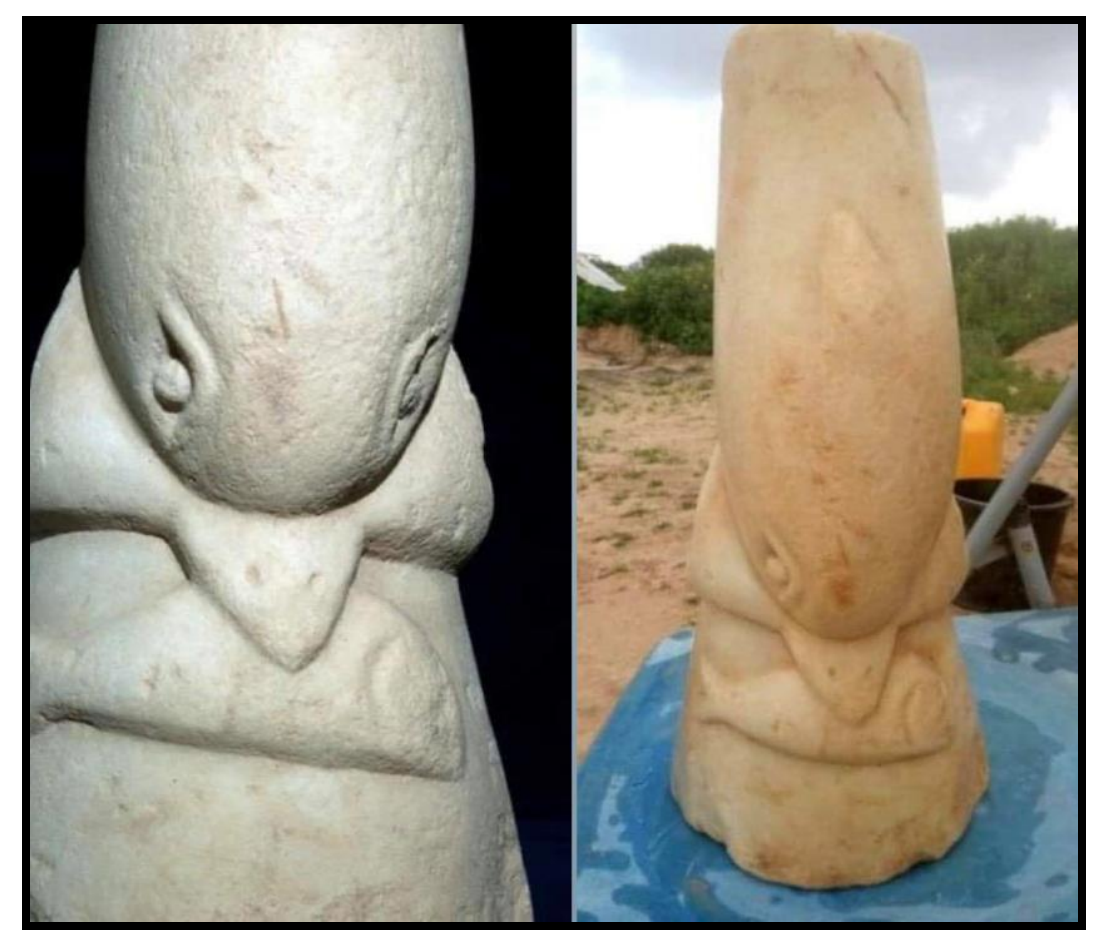

Figure (8): A Statuette of a Dolphin, Clutching A Fish Between Its Jaws, Found Near Kibbutz Magen, Near the Gaza Strip; 12 Miles Inland from the Mediterranean Sea [Source: Ben Zion, 
During the last 40 years, some old Gazan fishermen who used to fish far from the shore off the coast of Gaza or even the Egyptian coast admitted that they were able to see some baleen whales at sea for very short periods of time. Some of them saw the flukes of whales emerging from the water and some of them saw the water fountains emerging from the nostril opening. None of these fishermen was able to identify the whale species encountered or to give any accurate information about them. Despite this, the last whale strandings in and around the Gaza Strip were of dead specimens of the Fin Whale (Balaenoptera physalus) (Abd Rabou, 2014). Such strandings of this whale species; in particular, could be attributed to many reasons: The Fin whale is the most commonly observed mysticetes within the Mediterranean Sea (Stephens et al., 2021). It is a regular inhabitant of the Mediterranean Sea because of the feeding and reproductive needs the sea provides to the whale. The commonality of whale was acknowledged by Notarbartolo di Sciara et al. (2003) although the available evidence gives it a status as a visitor of the eastern Mediterranean basin as suggested by Kerem et al. (2012). The whale was known to strand in a variety of countries' coasts as revealed by Dede et al. (2012); Shoham-Frider et al. (2014), Abd Rabou (2020) and Stephens et al. (2021). Kerem et al., (2012) pointed out that many separate instances of single young individuals of the Fin Whale were encountered entering into Israeli harbors, either swimming in alive or floating in dead. Moreover, many Israeli parties confirmed the sighting of Fin Whales of different sizes in the Mediterranean waters including that of the Gaza Strip (Kerem et al., 2012).

Two dolphin species; namely the Common Bottlenose Dolphin and the Short-beaked Common Dolphin constituted the only toothed whales encountered as sighting or stranding cases in the Mediterranean waters of the Gaza Strip. The first is by far the most frequently encountered species year-round and along the $42-\mathrm{km}$ coastline of the Gaza Strip. These observations include calves and adults of different sizes. The majority of sightings were close to shore. The relative high number of Common Bottlenose Dolphin strandings in comparison to the other species suggests that this species is particularly abundant in the Palestinian shores of the Mediterranean (Reeves and Notarbartolo Di Sciara, 2006). The Common Bottlenose Dolphin is a regular Mediterranean inhabitant (Notarbartolo di Sciara and Birkun, 2010). Recent cetacean listings from neighboring eastern Mediterranean countries have the species 
ranking high on the list (Öztürk and Öztürk, 1998; Abd Rabou et al., 2007a; Gonzalvo and Bearzi, 2008). As far as the Israeli sightings of the dolphin in question are concerned, many group sightings were made; one of which were for 30 individuals including six calves, were sighted $50 \mathrm{~km}$ west of Gaza on August 2007. Similar results were found by El Hili et al. (2010) who studied the cetaceans stranded along the Tunisian northern-coasts. Although it was confirmed by local fishermen, no precise data on the number of dolphins suffering by getting caught in the Gazan fishing gear. The diet of the Common Bottlenose Dolphin consists mainly of eels, squid, shrimp and a wide variety of fishes (Brand et al., 2019). For this reason, many Gazan fishermen claimed the incidental by-catch of the species while fishing. According to Brand et al. (2019) the slender Balearic Eels (Ariosoma balearicum), which are frequently found protruding from the net's eyes, presumably making easy prey for dolphins.

The rarity of recording the Short-beaked Common Dolphin among the stranded dolphins in the Gaza Strip could be attributed to its general decline in the Mediterranean waters. According to Bearzi et al. (2003), the species used to be a common inhabitant of the Mediterranean Sea, but the past half century witnessed a clear decline in its range and the Mediterranean is now the last stronghold of its relative abundance as revealed by Notarbartolo di Sciara and Birkun (2010). Nowadays, the species in the Mediterranean is rare (Christensen, 2011) and is classified as a threatened status under the IUCN Red List (Bearzi et al., 2003). Even in Israel, the record is rather poor on strandings of the Short-beaked Common Dolphin (Kerem et al., 2012).

One of the most obvious reasons cited by the Gazans for the stranding and death of cetaceans was their exposure to fire by Israeli forces stationed in the Mediterranean Sea, or the suffocation of some dolphins due to their accidental fall into fishing nets. Nevertheless, in the course of the study, fishermen mentioned other causes of death and stranding of cetaceans, whether in the Gaza Strip or in other coastal areas of the world. In fact, incidents of shooting by Israel at naval targets are a common phenomenon of the Palestinian marine waters. Any Palestinian who lives in the Gaza Strip does not deny the shooting incidents because of their high density, as the Israeli 
army pursues Palestinian boats in the Israeli designated fishing area and sometimes kills or arrests Gazan fishermen, confiscates their boats and fishing equipment, or burns and destroys them. Abd Rabou (2020) pointed out that the Israelis believe that cetaceans are submarines, and that is why they automatically fire at them for security and military reasons.

In fact, the Palestinians did not undertake to take samples from stranded cetaceans to study the causes that led to their death and stranding. All it is for some Palestinians to film the events and display them on social media. On the other hand, the extent of the Israeli interest in cetaceans and marine mammals does not make their appearance and stranding an accident. Competent authorities rushed to take the necessary samples to document the causes of death for cetaceans, and this was what actually happened in the last dead Fin Whale thrown by marine waters in February 2021 in Majdal (Ashkelon), southern Palestine, and it was found that the whale died two weeks before its stranding and there seemed to be no connection to the oil pollution, which was prevalent at that time, with the death of that whale.

Accordingly, the causes of cetacean strandings on the coastline of the Gaza Strip, that were mentioned by Gazan fishermen and other marine parties, seemed to be logic, as many global studies on cetaceans and marine mammals showed such related causes. Aguilar and Borrell (1994) revealed dolphin mass mortalities by high levels of marine pollution, where abnormally high polychlorinated biphenyl levels were diagnosed in specimens of the Striped Dolphin (Stenella coeruleoalba). Entanglement in fishing gear and incidental captures were mentioned as a main threat to cetaceans as pointed out by Kuiken et al. (1994) and Kirkwood (1997). Parasitic diseases and injuries were known to threaten cetaceans as well (Lambertsen, 1992 and Luksenburg, 2014). Weilgart (2007) pointed out that the anthropogenic noise in oceans had negative impacts on cetaceans. The shooting incidents by the Israeli forces stationed in the Palestinian marine waters at some specimens of live or dead cetaceans that stranded on the shore of the Gaza Strip have been repeated under the pretext of security reasons and because they think that the bodies of cetaceans of all sizes may be submarines that may serve the Palestinians or some armed wings in the Gaza Strip. The killing of cetaceans by the Israelis for security reasons may not happen except in 
Palestinian marine waters and is rarely done by other forces around the world, but on the other hand, the use of firearms for euthanizing stranded whales and dolphins worldwide has been validated as pointed out by Hampton et al. (2004). As far as the climate change is concerned, it is a global environmental issue that dictates its harsh impacts on the global biodiversity, of which the marine mammals are a critical part as confirmed by Schumann et al (2013).

There are many Palestinian and non-Palestinian theories and conversations regarding the Israeli use of some animals for the purpose of spying on Palestinian resistance movements or on other countries. As for the use of dolphins for this task, it is not completely excluded. The Al-Qassam Brigades, the military wing of the Islamic Resistance Movement (Hamas), claimed that a dolphin was captured near the Gaza Strip with a camera and spy equipment in 2015. Despite the ambiguity and secrecy of the scene, it seems very possible, especially since news websites mention the attempts of many countries such as the United States of America, Russia and others to use different forms of animals, including dolphins, to spy and detect explosive devices in the deep sea. The discovery of a Beluga Whale (Delphinapterus leucas) in Norwegian waters that works for the Russian Navy has attracted the attention of the whole world, especially as Russia has a long history of using various forms of animals including whales and seals in espionage operations (Kirby, 2019 and Roache, 2019). The United States of America has also used the Common Bottlenose Dolphins (Tursiops truncatus) and California Sea Lions (Zalophus californianus) at a naval base in San Diego, California to patrol restricted waters and search for targets, and the program has been criticized by animal rights advocates for years, who consider it a violation of animals (Roache, 2019). 


\section{Conclusion}

In conclusion, the Mediterranean coast of the Gaza Strip is expected to be home to many cetacean faunistic species including the species revealed in the current study. There is an urgent need in the national, marine and scientific parties for a comprehensive and adequate survey of marine resources in the Gaza Strip, including fish and marine mammals, especially cetaceans. This requires the support of the marine scientific disciplines and the naval fleet capable of doing so. The role of different parties should be harmonized to ensure that human activities are sustainable and compatible with the mandate to preserve local marine natural resources including cetaceans.

\section{References}

Abd Rabou, A.N. (2013): Priorities of scientific research in the fields of marine environment and fishery resources in the Gaza Strip - Palestine. Priorities of Scientific Research in Palestine: Towards a National Directory of Scientific Research, March 25-26, 2013, Scientific Research Affairs, Islamic University of Gaza, Gaza Strip, Palestine, 481-522.

Abd Rabou, A.N. (2014): The Department of Marine Sciences at the Islamic University of Gaza has been able to identify a whale that was expelled by seawater on the shores of Rafah in 2009: Photos and video. Alwatan Voice Magazine (March 30, 2014). https://www.alwatanvoice.com/arabic/news/2014/03/30/515158.html.

Abd Rabou, A.N. (2020): The Palestinian marine and terrestrial vertebrate fauna preserved at the Biology Exhibition, Islamic University of Gaza, bombarded by the Israeli Army in December, 2008. Israa University Journal of Applied Science (IUGAS), 4(1): 9-51.

Abd Rabou, A.N.; Yassin, M.M.; Al-Agha, M.R.; Hamad, D.M. and Ali, A.S. (2007a): Wild mammals in the Gaza Strip, with particular reference to Wadi Gaza. The 
Islamic University Journal (Series of Natural Studies and Engineering), 15(1): 87-109.

Abd Rabou, A.N.; Yassin, M.M.; Saqr, T.M.; Madi, A.S.; El-Mabhouh, F.A.; Abu Nada, F.M.; Al-Masri, M.K.; Doulah, M.H. and Al-Haj Ahmad, M.M. (2007b): Threats facing the marine environment and fishing in the Gaza Strip: Field and literature study. Theme XII: Environmental Design Trends and Pollution Control, The 2nd International Engineering Conference on Construction and Development (IECCD-II), Islamic University of Gaza, Gaza Strip, Palestine, September 3-4, 2007, 11-31.

Abd Rabou, A.N.; Musallam, N.J.; Musallam, E.J.; Elkahlout, K.E.; Elnabris, K.J.; ElBashiti, T.A.; Abdel Aziz, I.I; Ishneiwra, R.M.; Radwan, E.S.; Saada, H.S.; Shafei, A.A.; Fayyad, N.A.; Mwafy, S.N.; Abu Amra, H.E.; Abu Al-Ajeen, R.A.; Abu Owda, M.F.; Alfarra, R.N.; Hassouna, H.A.; Hassouna, R.A.; AlAgha, M.R. and Abd Rabou, M.A. (2020): The Palestinian terrestrial vertebrate fauna preserved at the biology exhibitions of the universities of the Gaza Strip. Research in Ecology, 2(4): 9-21.

Abo-Taleb, H.A.; El-Feky, M.M.; El-Tabakh, M.A.M.; Dina, M. Hendy, D.M. and Maaty, M. (2020): First record of Bryde's Whale (Balaenoptera brydei, Olsen, 1913) in the southeastern Mediterranean Sea, Alexandria, Egypt. Egyptian Journal of Aquatic Biology \& Fisheries, 24(1): 667-695.

Aguilar, A. and Borrell, A. (1994): Abnormally high polychlorinated biphenyl levels in Striped Dolphin (Stenella coeruleoalba) affected by the 1990-1992 Mediterranean epizootic. Science of the Total Environment, 154: 237-247.

Baldwin, R. (2003): Whales and dolphins of Arabia. Mazoon Printing Press, Muttrah, Sultanate of Oman, $111 \mathrm{pp}$.

Baldwin, R.M.; Collins, M.; Van Waerebeek, K. and Minton, G. (2004): The IndoPacific Humpback Dolphin of the Arabian region: A status review. Aquatic Mammals, 30(1): 111-124.

Bazairi, H.; Ben Haj, S.; Boero, F.; Cebrian, D.; De Juan, S.; Limam, A.; Lleonart, J.; Torchia, G., and Rais, C. (2010): The Mediterranean Sea biodiversity: State of the ecosystems, pressures, impacts and future priorities. UNEP-MAP RAC/SPA, Tunis, 100 pp. 
Bearzi, G. (2003): Delphinus delphis (Mediterranean subpopulation). The IUCN Red List of Threatened Species 2003: e.T41762A10557372. http://dx.doi.org/10.2305/IUCN.UK.2003.RLTS.T41762A10557372.en.

Bearzi, G. (2017): Action plan for marine mammals in Israel, 2017-2022. Israel Marine Mammal Research \& Assistance Center (IMMRAC), 101 pp.

Bearzi. G.; Agazzi, S.; Gonzalvo, J.; Costa, M.; Bonizzoni, S.; Politi, E.; Piroddi, C. and Reeves, R.R. (2008): Overfishing and the disappearance of Short-beaked Common Dolphins from western Greece. Endangered Species Research, 5: 112.

Bearzi. G.; Reeves, R.R.; Notarbartolo di Sciara, G.; Politi, E.; Conadas, A.; Frantzis, A. and Mussi, B. (2003): Ecology, status and conservation of Short-beaked Common Dolphins Delphinus delphis in the Mediterranean Sea. Mammal Review, 33: 224-252.

Benmessaoud, R.; Cherif, M.; Bradai, M.N. and Bejaoui, N. (2012): Distribution of Bottlenose Dolphin around Kelibia (Northeastern of Tunisia). Asian Journal of Contemporary Sciences, 1: 1-11.

Benmessaoud, R.; Cherif, M.; Karaa, S. and Koched, W. (2020): Demography and social structure of resident population of Bottlenose Dolphin in Tunisian North-eastern coasts. Bulletin de l'Institut National des Sciences et Technologies de Mer de Salammbô, 47: (In Press).

Ben Zion, I. (2015): Mysterious 2,000-year-old marble dolphin surfaces near Gaza. The Times of Israel, 25 June 2015, https://www.timesofisrael.com/2000-yearold-marble-dolphin-surfaces-near-gaza-strip/.

Boitani, L. and Bartoli, S. (1983): Simon and Schuster's Guide to Mammals. Simon and Schuster Inc., $511 \mathrm{pp}$.

Bouslah, Y.; Larbi Doukara, K.; Bouderbala, M.; Merzoug, D. and Boutiba, Z. (2016): First record and trace element concentration in Humpback Whale (Megaptera Novaeangliae) stranding on the coast of Algeria (southwestern Mediterranean Sea). International Journal of Sciences: Basic and Applied Research (IJSBAR), 26: $405-414$.

Brand, D.; Edelist, D.; Goffman, O.; Hadar, N.; Scheinin, A. and Kerem, D. (2019): Common Dolphins, common in neritic waters off southern Israel, demonstrate 
uncommon dietary habits. Aquatic Conservation: Marine and Freshwater Ecosystems. 1-7, https://doi.org/10.1002/aqc.3165.

Castro, p. and Huber, M.E. (2009): Marine biology, 7th edition, McGraw-Hill, 459 pp.

Christensen, V. (2011): From common to rare: the case of the Mediterranean common dolphin. Biological Conservation, 144: 2490-2498.

Dawoud, W.A.; Negm, A.M.; Saleh, N.M. and Bady, M.F. (2016): Impact assessment of offshore pile driving noise on Red Sea marine mammals. International Journal of Environmental Science and Development, 7(1):10-15.

Dede, A.; Saad, A.; Fakhri, M. and Öztürk, B. (2012): Cetacean sightings in the Eastern Mediterranean Sea during the cruise in summer 2008. Journal of Black Sea/Mediterranean Environment, 18(1): 49-57.

El Hili, H.A.; Cozzi, B.; Ben Salah, C. Podesta, M.; Ayari, W.; Ben Amor, N. and Mraouna, R. (2010): A survey of cetaceans stranded along the northern coast of Tunisia: Recent findings (2005-2008) and a short review of the literature. Journal of Coastal Research, 26(5): 982-985.

Euroconsult and IWACO (1994): Gaza environmental profile (Part I): Inventory of resources. Palestinian Environmental Protection Authority, Gaza StripPalestine, $60 \mathrm{pp}$.

Farrag, M.M.S.; Ahmed, H.O.; TouTou, M.M.M. and Eissawi, M.M. (2019): Marine mammals on the Egyptian Mediterranean Coast: Records and vulnerability. International Journal of Ecotoxicology and Ecobiology. 4(1): 8-16.

Gaspari, S.; Scheinin, A.; Holcer, D.; Fortuna, C.; Natali, C.; Genov. T. and Moura, A.E. (2015): Drivers of population structure of the Bottlenose Dolphin (Tursiops truncatus) in the eastern Mediterranean Sea. Evolutionary Biology, 42: $177-190$.

Goffman, O.; Roditi, M.; Shariv, T.; Spanier, E. and Kerem, D. (2000): Cetaceans from the Israeli coast of the Mediterranean Sea. Israel Journal of Zoology, 46: 143-147.

Gonzalvo, J. and Bearzi, G. (2008): Action Plan for the conservation of cetaceans in Syria. Regional Activity Centre for Specially Protected Areas, Contract 39/2007-RAC/SPA; 2008. 
Hampton, J.O.; Mawson, P.R.; Coughran, D.K. and Vitali, S.D. (2014): Validation of the use of firearms for euthanizing stranded Cetaceans. Journal of Cetacean Research and Management, 14(1): 117-123.

IUCN (2012): Marine mammals and sea turtles of the Mediterranean and Black Seas. Gland, Switzerland and Malaga, Spain: IUCN, 32 pp.

Jerusalem Post Staff (2021): Sperm Whale spotted off Israeli coast in rare sighting watch. THE JERUSALEM POST, February 28, 2021, https://www.jpost.com/israel-news/sperm-whale-spotted-off-israeli-coast-inrare-sighting-660375.

Kerem, D.; Goffman, O. and Spanier, E. (2001): Sighting of a single Humpback Dolphin (Sousa sp.) along the Mediterranean coast of Israel. Marine Mammal Science, 17(1): 170-171.

Kerem, D.; Hadar, N.; Goffman, O.; Scheinin, A.; Kent, R.; Boisseau, O. and Schattner, U. (2012): Update on the cetacean fauna of the Mediterranean Levantine Basin. The Open Marine Biology Journal, 6: 6-27.

Khalaf, G.; Fakhri, M.; Ohanian, C.; Abi-Ghanem, C. and David, L. (2003): Distribution and relative abundance of the Tursiops truncatus in Lebanese marine waters (Eastern Mediterranean). Journal of Life Sciences, 7(11): 1-8.

Khalaf, N.A. (2008): Cetacea Palaestina: The whales and dolphins in Palestinian waters. Cetacean species guide for Palestine. Gazelle: The Palestinian Biological Bulletin, 83: 1-14.

Khalaf, N.A. (2012): Gray Whale (Eschrichtius robustus Lilljeborg, 1861) sighted off the Mediterranean coast of Palestine. Gazelle: The Palestinian Biological Bulletin, 100: 1-6.

Khalaf, N.A. (2019): Whales from the Gaza Strip, Sea of Gaza, State of Palestine. Gazelle: The Palestinian Biological Bulletin, 180: 1-17.

Khalaf, N.A. (2021a): First record of the Killer Whale (Orcinus orca Linnaeus, 1758) off the coasts of Akka (Acre) and Nahariya, Northern Occupied Palestine, and Beirut, Lebanon. Gazelle: The Palestinian Biological Bulletin, 200: 1-17.

Khalaf, N.A. (2021b): A Common Bottlenose Dolphin (Tursiops truncatus Montagu, 1821) stranding on Khan Yunis shore, southern Gaza Strip, State of Palestine. Gazelle: The Palestinian Biological Bulletin, 39(201): 1-21. 
Khalaf, N.A. (2021c). First record of the Northern Indian Ocean Blue Whale (Balaenoptera musculus indica Blyth, 1859) in Palestinian waters, Gulf of Aqaba, Red Sea. Gazelle: The Palestinian Biological Bulletin, 39(202): 1-27.

Kirby, D. (2019): Russia's spy whale is not the first animal to be used for secret warfare. I NEWS (May 3, 2019), https://inews.co.uk/news-/world/russiabeluga-spy-whale-animals-nature-wildlife-norway-287616.

Kirkwood, J.K.; Bennett, P.M.; Jepson, P.D.; Kuiken, T.; Simpson, V.R. and Baker, J.R. (1997): Entanglement in fishing gear and other causes of death in cetaceans stranded on the coasts of England and Wales. The Veterinary Record, 141: 94-98.

Kuiken, T.; Simpson, V.R.; Allchin, C.R.; Bennett, P.M.; Codd, G.A.; Harris, E.A.; ... and Phillips, S. (1994): Mass mortality of Common Dolphins (Delphinus delphis) in south west England due to incidental capture in fishing gear. The Veterinary Record, 134: 81-89.

Lambertsen, R.H. (1992): Crassicaudosis: A parasitic disease threatening the health and population recovery of large baleen whales. Revue scientifique et technique (International Office of Epizootics), 11(4): 1131-1141.

Larbi Doukara, K. (2019): A stranding record of the Short-beaked Common Dolphin (Delphinus delphis) in Algerian West Coast, during 2008-2012. Aquatic Conservation: Marine and Freshwater Ecosystems, 1-7.

Larbi Doukara, K.; Bouslah, Y.; Bouderbala, M. and Boutiba, Z. (2014): Heavy metals in soft tissues of Short-Beaked Common Dolphins (Delphinus delphis) stranded along the Algerian west coast. Open Journal of Marine Science, 4: $110-117$.

Lloyd, H. and Ross, G. (2015): Long-term trends in cetacean incidents in New South Wales, Australia. Australian Zoologist, 1-9.

Luksenburg, J.A. (2014): Prevalence of external injuries in small cetaceans in Aruban waters, southern Caribbean. PLoS ONE, 9(2): e88988. doi:10.1371/ journal.pone.0088988.

Mahdy, A.; Ghallab, A.; Madkour, H. and Osman, A. (2021): Status of Indo-Pacific Bottlenose Dolphin, Tursiops aduncus (Family Delphinidae: Order Cetacea) in 
the Northern Protected Islands, Hurghada, Red Sea, Egypt. Egyptian Journal of Aquatic Biology \& Fisheries, 25(1): 681-697.

Masski, H. and De Stephanis, R. (2018): Cetaceans of the Moroccan coast: Information from a reconstructed strandings database. Journal of the Marine Biological Association of the United Kingdom, 98(5): 1029-1037.

MEnA, (2001): Gaza Coastal and marine environmental protection and management action plan. Ministry of Environmental Affairs (MEnA), Palestinian National Authority, Gaza City (Palestine). 112 PP.

Noonpost (2016): https://www.noonpost.com/content/15207.

Notarbartolo di Sciara, G.; Kerem, D.; Smeenk, C.; Rudolph, P.; Cesario, A.; Costa, M.; Elasar, M.; Feingold, D.; Fumagalli, M.; Goffman, O.; Hadar, N.; Mebrathu, Y.T. and Scheinin, A. (2017): Cetaceans of the Red Sea. CMS Technical Series 33, $86 \mathrm{pp}$.

Notarbartolo di Sciara, G.; Politi, E.; Bayed, A.; Beaubrun, P. and Knowlton, A. (1998): A Winter Cetacean Survey off Southern Morocco, With a Special Emphasis on Right Whales. Report - International Whaling Commission, 48: 547-551.

Notarbartolo di Sciara, G.; Zanardelli, M.; Jahoda, M.; Panigada, S. and Airoldi, S. (2003): The Fin Whale Balaenoptera physalus (L. 1758) in the Mediterranean Sea. Mammal Review, 33: 105-50.

Notarbartolo di Sciara, G. and Birkun A. Jr. (2010): Conserving whales and dolphins in the Mediterranean and Black Seas: An ACCOBAMS status report. ACCOBAMS, Monaco. 212 pp.

Öztürk, A.A.; Tonay, A.M. and Dede, A. (2011): Strandings of the Beaked Whales, Risso's Dolphins, and a Minke Whale on the Turkish coast of the Eastern Mediterranean Sea. J Black Sea/Med Environ, 17: 269-274.

Öztürk, B. and Öztürk, A.A. (1998): Cetacean strandings in the Aegean and Mediterranean coasts of Turkey. Rapp Comm Int Mer Médit., 35: 476-77.

Reeves, R. and Notarbartolo di Sciara, G. (2006): The status and distribution of cetaceans in the Black Sea and Mediterranean Sea. IUCN Center for Mediterranean Cooperation, Malaga, Spain, 137 pp. 
Rizgalla, J. (2020): Live stranded Fin Whale Balaenoptera physalus in Libyan waters reported via social media platform. Journal of Black Sea/Mediterranean Environment, 26(3): 329-335.

Roache, M. (2019): A Beluga Whale is allegedly a Russian spy. There's a long history of marine mammals in the military. TIME (May 3, 2019), https://time.com/5582694/russian-spy-whale-history/.

Rojo-Nieto, E.; Álvarez-Díaz, P.D.; Morote, E.; Burgos-Martín, M.; MontotoMartínez, T.; Sáez-Jiménez, J. and Toledano, F. (2011): Strandings of cetaceans and sea turtles in the Alboran Sea and Strait of Gibraltar: A longtime glimpse of the north coast (Spain) and the south coast (Morocco). Animal Biodiversity and Conservation, 34(1): 151-163.

Saad, A. (2004): First record of a Humpback Whale stranding on the coast of Syria (Eastern Mediterranean). ACCOBAMS Fins Newsletter, 1(1): 10.

Scheinin, A.P.; Goffman, O.; Elasar, M.; Perelberg, A. and Kerem, D.H. (2011): Mediterranean Monk Seal (Monachus monachus) resighted along the Israeli coastline after more than half a century. Aquatic Mammals, 37(3): 241-242.

Scheinin, A.P.; Kerem, D.; Lojen, S.; Liberzon, J and Spanier, E. (2014): Resource partitioning between Common Bottlenose Dolphin (Tursiops truncatus) and the Israeli bottom trawl fishery: Assessment by stomach contents and tissue stable isotopes analysis. Journal of the Marine Biological Association of the United Kingdom, 94(6): 1203-1220.

Schumann, N.; Gales, N.J.; Harcourt, R.G. and Arnould, J.P.Y. (2013): Impacts of climate change on Australian marine mammals. Australian Journal of Zoology, 61: 146-159.

Sharir, Y. (2008): Morphometric characteristics of the Common Bottlenose Dolphin (Tursiops truncatus) population in the Levant Basin. Master Thesis, University of Haifa, Israel.

Shoham-Frider, E..; Amiel, S.; Roditi-Elasar, M. and Kress, N. (2002): Risso's Dolphin (Grampus griseus) stranding on the coast of Israel (eastern Mediterranean): Autopsy results and trace metal concentrations. The Science of the Total Environment, 295: 157-166. 
Shoham-Frider, E.; Goffman, O.; Harlavan, Y.; Kress, N.; Morick, D.; Roditi-Elasar, M.; Shefer, E. and Kerem, D. (2016): Trace elements in Striped Dolphins (Stenella coeruleoalba) from the Eastern Mediterranean: a 10-years perspective. Marine Pollution Bulletin, 109: 624-632.

Shoham-Frider, E.; Kerem, D.; Roditi-Elasar, M.; Goffman, O.; Morick, D.; Yoffe, O. and Kress, N. (2014): Trace elements in tissues of cetacean species rarely stranded along the Israeli Mediterranean coast. Marine Pollution Bulletin, 83(1): 376-382.

Shoham-Frider, E.; Kress, N.; Wynne, D.; Scheinin, A.; Roditi-Elasar, M. and Kerem, D. (2009): Persistent organochlorine pollutants and heavy metals in tissues of Common Bottlenose Dolphin (Tursiops truncatus) from the Levantine Basin of the eastern Mediterranean. Chemosphere, 77(5): 621-627.

Spanier, E.; Goffman, O.; Kerem, D. and Lavalli, K. (2000): Injury of an Indian Ocean Bottlenose Dolphin (Tursiops aduncus) in the Red Sea by a stingray spine. Aquatic Mammals, 26(3): 196-201.

Stephens, G.; Baş, A.A.; Hardy, J.; Awbery, T.; Rudd, L.; Abbiss, L.; Araç, N. and Lyne, P. (2021): Sightings and stranding reports of fin whales (Balaenoptera physalus) in the Levantine Sea. Journal of Cetacean Research and Management, 22: 55-60.

Taleb, M.Z. and Boutiba, Z. (1999): The organochlorine compounds: Threat to the cetaceans of the Algerian waters. Proceedings of the 13th Annual ECS Conference, Valencia, 5-8 April 1999, 25-30.

TOI Staff (2020): Killer Whale spotted off the coast of Israel. THE TIMES OF ISRAEL, February 28, 2020, https://www.timesofisrael.com/killer-whalespotted-off-the-coast-of-israel/

UNEP (2003): Desk study on the environment in the Occupied Palestinian Territories. United Nations Environment Program (UNEP), Nairobi, Kenya, 188 pp.

UNEP/IUCN (1994): Technical report on the state of cetaceans in the Mediterranean. Mediterranean Action Plan Technical Reports Series No. 82, United Nations Environment Program (UNEP), Regional Activity Centre for Specially Protected Areas, Tunis, $37 \mathrm{pp}$. 
Weilgart, L.S. (2007): The impacts of anthropogenic ocean noise on cetaceans and implications for management. Canadian Journal of Zoology, 85: 1091-1116.

Weitkowitz, W. (1992): Sightings of whales and dolphins in the Middle East (Cetacea), Zoology in the Middle East, 6 (1): 5-12. 